\title{
THE SIGNIFICANCE OF HEREDITY IN OPHTHALMOLOGY. PRELIMINARY SURVEY OF HEREDITARY EYE DISEASES IN TASMANIA*
}

\author{
BY
}

\author{
J. BRUCe Hamilton \\ HOBART, TASMANIA
}

\section{Geographical}

The island of Tasmania is heart-shaped in outline, and has an area of 26,215 square miles and a population of 227,599. The capital-Hobart-which is in the south of the island, has a population of 60,406 and a surrounding urban population of about 50,000 . In the north of the island are roughly another 110,000 people- 32,841 of whom live in the city of Launceston, the chief civic centre of that part of the island.

\section{Historical}

Although Van Diemen's Land was discovered by a Dutchman -Abel Jansen Tasman-on November 24, 1642, yet it was the English who formed in 1803 the first settlement on the island, which has remained a British possession ever since. At first it was entirely a penal settlement, but by 1815 free settlers had commenced to arrive, and in 1853 transportation of convicts terminated. In 1856 the island was declared a Crown Colony, and the name changed to Tasmania in memory of its discoverer; while in 1901 a Federation of Australian States and Tasmania was formed, and this Federation is now known as the Commonwealth of Australia.

It appears to be a significant fact that while Colonel David Collins was founding the first permanent settlement in Tasmania, in the form of a penal settlement in July, 1804, John Cunningham Saunders was circulating to the wealthy merchants of London his appealing letter dated October 1, 1804, which resulted in the foundation of Moorfields Eye Hospital in March of the following year. In St. David's Park, Hobart, stand several historic monuments, on one of which is inscribed the following epitaph :-

"To the memory of David Collins, Esq., Lieutenant Governor of the Colony, and Lieutenant Colonel of the Royal Marine Forces. On the first establishment of the Colony of New South Wales he was employed as Deputy Judge Advocate. And in the year 1803 he was entrusted by His Majesty's Government with the command of an expedition destined to form a settlement at 
Port Phillip on the south coast of New Holland, which was subsequently removed to Van Diemen's Land. Under his direction as Lieutenant Governor the site of this town was chosen, and the foundation of its first building laid in 1804. He died here on March 28, 1810, aged 56 years, and this monument long projected, was erected to his memory in 1838, by direction of His Excellency Sir John Franklin, K.C.H.K.R. Site of the first church erected in 1810 in Van Diemen's Land. Built over the grave of Lieutenant Governor Collins, whose body rested beneath the Altar."

In the present hall of the Royal London Ophthalmic (Moorfields) Hospital stands a bust with the curt inscription, " John Cunningham Saunders-Founder, MDCCCIV. This bust erected -March 25th, 1845."

But unfortunately the progress of Tasmania was very retarded, for it was not until 1853 that the transportation of convicts to the island was abolished, and the island commenced its history as a Colony of the Crown. The progress of ophthalmology in the island was equally retarded, and it was not until the advent of the present decade that there was a surgeon in the island who devoted his entire attention to eye work. Unfortunately no serious attempt has been made up to the present to record local observations on eye disease, and I am able to find in the literature only one article on Hereditary Eye Disease in Tasmania.

Consequently this survey has been a pioneer work, and an extremely difficult one; first because naturally many of the local inhabitants are very reticent about their antecedents, and resent strongly any probings into the past; and secondly, because the population is so sparse and scattered. (It is well to remember here that the total population of Tasmania is only $1 / 30$ of that of London); and thirdly, relatives of diseased persons reside in many parts of Australia which are beyond the reach of an ophthalmic surgeon. As a result, most of my pedigrees to date are short, except for one or two obvious exceptions, and these exceptions have taken much tact and time to obtain.

One has only to read Usher's Bowman Lecture of 1935, to realise with what infinite pains Nettleship and his disciples have striven in an attempt to correlate their findings, and to present the subject of heredity from the ocular standpoint. When I first read Julia Bell's monograph, I felt that the subject had been more or less exhaustively dealt with. Now that I have perused the literature to some extent I find that so far as she went, Julia Bell acquitted herself well, but unfortunately her work was not completed. There is no monograph in the Nettleship Memorial volume on congenital cataracts, ptosis, epicanthus, or squint, or coming down to the bread and butter of every oculist-on refractive errors. This gap should be filled in as speedily as possible. 


\section{Statistical}

According to the Commonwealth Census of 1933, the population of Tasmania was estimated as 227,599, and the Commonwealth Bureau of Census and Statistics has supplied me with the following vital statistics in regard to Tasmania :-

Number of people in Tasmania $\quad \ldots \quad \ldots \quad \ldots \quad \ldots \quad 227,599$

Number of people born in Australia (only available) 214,839

Number born outside Australia, excluding 389 birth$\begin{array}{lllllll}\text { place unspecified } & \ldots & \ldots & \ldots & \ldots & \ldots & 12,371\end{array}$

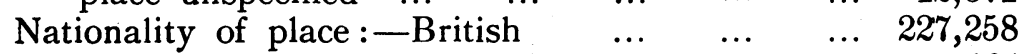

$\begin{array}{lllll}\text { Chinese } & \ldots & \ldots & \ldots & 104\end{array}$

$\begin{array}{llllr}\text { Italian } & \ldots & . . & \ldots & 80\end{array}$

$\begin{array}{lllll}\text { German } & \ldots & \ldots & \ldots & 23\end{array}$

United States of America... 26

Others $\quad \ldots \quad \ldots \quad \ldots \quad 108$

Except for a few Chinese gardeners and one or two half-castes from the Strait Islands of Flinders and Cape Barren, the population of Tasmania is purely Caucasian, and almost purely British stock; so that the pedigrees to follow should and do closely correspond to those more elaborate ones worked out by Nettleship in England; and Usher in Scotland.

\section{REFERENCES}

\section{HISTORICAL}

Collins, T. (1928).-The History and traditions of Moorfields Eye Hospital, London.

Commonwealth of Australia (1935).--Official Year Book.

STALLARD H. B. (1936).-Personal communication.

STATISTICAL

Commonwealth of Australia (1935).-Official Year Book, p. 514.

Commonwealth Bureau of Census.-Personal Communication and Stitistics (1936)

\section{Heredity and Ophthalmology}

The proportion of hereditary disease in Tasmania is difficult to define, but I shall presently attempt to make a rough estimate. On the other hand the preponderance of hereditary blindness in this State, which will be discussed later, can be defined with much greater certainty.

Of 4,880 private patients with eye diseases, seen by me during the last $5 \frac{1}{2}$ years -119 have proved to be authentically hereditary in origin, which makes a case incidence of 244 per cent., or roughly $2 \frac{1}{2}$ in every hundred. This figure I am sure is somewhat low, chiefly due to the fact that during the first $3 \frac{1}{2}$ years I was not vitally interested in the subject of heredity, and therefore did not take much pains to elicit family histories from patients who 
did not volunteer the information or in whose interest the matter of heredity was of little or no clinical importance. Of course 119 is not the total number of patients examined for these pedigrees, for many others have been examined by me in hospital work, or by my colleagues or their predecessors in private practice in Tasmania.

\section{Diseases associated with Hereditary Eye Detects}

The association of hereditary defects of the eye, with hereditary defects in other parts of the body is a peculiarly interesting branch of the subject under discussion, and yet it appears to have received

\section{TABLE I}

Hereditary Abnormalities of the Nervous System, associated with Eye Defects

\begin{tabular}{|c|c|}
\hline Nervous System & EYE \\
\hline Amaurotic family idiocy & $\begin{array}{l}\text { Cherry red spot at macula and } \\
\text { optic atrophy }\end{array}$ \\
\hline $\begin{array}{l}\text { Angiomatous cysts of the cere- } \\
\text { bellum. (Lindau's disease) }\end{array}$ & Angiomatosis of the retina \\
\hline Cerebral angioma & Buphthalmos \\
\hline Dystrophia myotonica & Cataract \\
\hline $\begin{array}{l}\text { Familial hypertrophic neuritis } \\
\text { (Dejerine-Sottas) }\end{array}$ & $\begin{array}{l}\text { Nystagmus and abnormal pupil } \\
\text { reactions }\end{array}$ \\
\hline Friedreich's ataxia & Nystagmus \\
\hline $\begin{array}{l}\text { Hepato-lenticular degeneration } \\
\text { (Wilson' disease) }\end{array}$ & Kayser-Fleischer ring of cornea \\
\hline Hereditary cerebellar ataxia & Optic atrophy \\
\hline Mental retardation & $\begin{array}{l}\text { Lens opacities } \\
\text { Colour blindness } \\
\text { High astigmatism } \\
\text { Myopia } \\
\text { Squint } \\
\text { Albinism } \\
\text { Opaque nerve fibres }\end{array}$ \\
\hline Mongolism & Keratoconus \\
\hline $\begin{array}{l}\text { Neurofibromatosis. (von Reck- } \\
\text { linghausen's disease) }\end{array}$ & Tumours of retina and iris \\
\hline $\begin{array}{l}\text { Tuberose sclerosis. (Bourne- } \\
\text { ville's disease) }\end{array}$ & Cysts of the retina \\
\hline
\end{tabular}


scant appreciation. Accordingly I append three tables of such associated defects met in the literature, and possibly other writers could add further examples of their own. More particularly does hereditary eye disease appear to be associated with corresponding defects of the nervous and skeletal systems (see Tables I and II), but outside these categories there are a few other associated diseases, especially the Laurence-Moon-Biedl-Syndrome. (See Table III. These will be referred to again.

\section{TABLE II}

Hereditary Digital Anomalies in relation to Eye Defects

\begin{tabular}{l|l}
\hline \multicolumn{1}{c|}{ Digits } & \multicolumn{1}{c}{ EYE } \\
\hline $\begin{array}{l}\text { Syndactyly } \\
\text { Arachnodactyly }\end{array}$ & $\begin{array}{l}\text { Aniridia } \\
\text { Eolydactyly } \\
\text { Brachydactyly } \\
\begin{array}{l}\text { Doubling of thumbs with } \\
\text { atrophy of terminal phalanges }\end{array}\end{array}$ \\
\hline
\end{tabular}

TABLE III

Miscellaneous Hereditary Abnormalities, associated with Eye Defects

\begin{tabular}{l|l}
\hline \multicolumn{1}{c|}{ Miscellaneous } & \multicolumn{1}{c}{ EYE } \\
\hline Aortic stenosis & $\begin{array}{l}\text { Ectopia lentis } \\
\text { Eighth nerve deafness }\end{array}$ \\
Fragilitas ossium & Retinitis pigmentosa \\
Harelip & Mye sclerotics \\
& Microphthalmos \\
Hypogenitalism and obesity & Retinitis pigmentosa \\
(Laurence-Moon-Biedl syn- & \\
drome) & Blue sclerotics \\
Stammering & Nystagmus \\
\hline
\end{tabular}




\section{Possible Hereditary Eye Defects}

From Ruggles Gates (1929), and Duke-Elder (1934), and Van Duyse (1933) I have been been able to tabulate the following 44 hereditary eye diseases in alphabetical order.

O Albinism.

Amaurotic family idiocy.

Angiomatosis of retina (Lindau's Disease).

$\mathrm{O}$ Aniridia.

Anophthalmos.

Arcus juvenilis (Embryotoxon).

$\mathrm{X}$ Astigmatism.

Blue sclerotics.

O Buphthalmos.

$\mathrm{X}$ Cataracts, congenital (including Dystrophia Myotonica). Cataracts-senile.

Choroideremia.

O Coloboma of iris, lens and choroid.

O Colour blindness.

Corneal opacities-nodular.

Corneal pigmentation (hepato-lenticular degeneration).

Cryptophthalmos.

Distichiasis.

O Ectopia lentis.

O Epicanthus.

Glaucoma. Congenital (not buphthalmos).

$\mathrm{X}$ Glaucoma. Senile.

Glioma of retina.

Gyrate atrophy of retina and choroid.

O Hypermetropia.

$\mathrm{X}$ Keratoconus.

Lagophthalmos.

O Megalocornea.

Microcornea.

$\mathrm{X}$ Microphthalmos.

$\mathrm{X}$ Myopia.

Night blindness.-Stationary.

$\mathrm{X}$ Nystagmus.

Optic atrophy.-Congenital.

$\mathrm{X}$ Optic atrophy. Hereditary (Leber's Disease).

Ophthalmoplegia.

$\mathrm{X}$ Pterygium.

$\mathrm{X}$ Ptosis.

X Retinal detachment. 
$\mathrm{X}$ Retinitis pigmentosa.

Retinitis pigmentosa sine pigmento.

Retinitis punctata albescens.

$\mathrm{X}$ Strabismus.

Tapeto-retinal degeneration (Weber).

In this list I have marked (X) against those diseases of which I have been able to obtain pedigrees in Tasmania; while (O) indicates that isolated cases of these diseases have been examined by me, but no definite hereditary evidence obtained.

Before dealing with each of these thirteen hereditary eye diseases, I propose to examine the causes of hereditary blindness in Tasmania, and the sociological problems of those afflicted in this State. When this is accomplished, then the diseases will be discussed in conjunction with their respective pedigrees.

\section{REFERENCES}

BeLl, J. (1933).-Trans. Ophthal. Soc. U.K., Vol. LIII, p. 42.

BELL, J. (1922-32).-Treasury of Human Inheritance, Vol. II, parts 1-5.

BEST, H. (1934).-Blindness and the Blind in U.S.A. New York.

BLACKER, C. P. (1934). - The Chances of Morbid Inheritance. London.

BigGs, H. H. (1919).-Amer. Jl. Ophthal., Vol. Vol. XI, p, 408

Clausen, H. (1923).-Zentrulb. fur die gesamte Ophthal. und ihre grenzgebiete, Vol. XI, 3, p. 81 .

Clausen, H. (1923).-Zentralb. fur die gesamte Ophthal. und ihre grenzgebiete, Vol. XI, 6, p. 209.

Clausen, H. (1923).-Zentralb. fur die gesamte Ophthal. und ihre grenzgebiete, Vol. XI, 10 , p. $41 \%$

Clausen, H. (1923).-Zentralb. fur die gesante Ophthal. und ihre grenzgebiete, Vol. XI, 11, p. 481.

CoOper, E. L. (1936).-Brit. Med: Jl., A pril 18, p. 793.

CREW, F. A. (1926).-Brit. Med. Jl., August 14, p. 225.

Gates, R. G. (1929).-Heredity in Man. London.

Hudson, A. C. (1932). -Proc. Roy. Soc. Med., Vol. XXVI, p. 35.

KING, E. F. (1934).-Proc. Roy. Soc. Med., Vol. XXVII, p. 298.

MaNN, I. C. (1933) -Trans. Ophthal. Soc. U.K., Vol. LIII, p. 47.

MOORE, E. (1934).-Heredity-Mainly Human. London.

Moore, R. Foster (1925).-Medical Ophthalmology. London.

PunNetT, R C. (1933) - Trans. Ophthal. Soc. U.K., Vol. I.III, p. 9.

Sorsby, A. (1934) - Proc. Roy. Soc. Med., Vol. XXVII, p. 694.

TIDY, H. L. (1934).-Synopsis of Medicine. London.

vaN Der Hoeve, J. (1932).-Trans. Ophthal, Soc. U.K., Vol. LII, p. 380.

VAN DUY=E (1933).-Trans. Ophthal. Soc. U.K., Vol. LIII, p. 29.

WhishaW, R. (1936).-Personal Communication.

Wilson, S. A. (1934).-Proc. Roy. Soc. Med. Vol. XXVII, p. 297.

\section{Causes of Hereditary Blindness in Tasmania}

While ophthalmia neonatorum, trachoma, and smallpox are the three main causes of blindness in Europe, Asia and Africa, these causes are insignificant in Tasmania. First ophthalmia neonatorum of the true gonococcal type is rare in this island, and only 
one child between 7 and 16 is at present suffering from blindness as the result of this disease; and actually the exact causal organism of his ophthalmia is not known with certainty. Secondly, trachoma is almost non-existent, and I have only seen four fresh cases and four old ones in $5 \frac{1}{2}$ years of private practice, and none in public hospital work. Thirdly, smallpox does not exist in Tasmania at all.

If we review the blind in Tasmania, we will find that blindness in the island is attributable to a considerable extent to hereditary defects.

However disabling most hereditary eye diseases may be, those which cause blindness are paramount in importance, for it is common knowledge that guided by our special senses, our existence depends say $4 / 5$ on eye sight, and $1 / 5$ on the other senses. I have therefore no doubt in writing that the blind are at least 80 per cent. handicapped, and when Best (1934) assures us that only 7 per cent. of the blind in the United States of America are self supporting, and the League of Nations Reports (1929) that 65 per cent. of the blind are unemployable, I feel this figure of 80 per cent. may be too low. To my mind the greatest significance of heredity in ophthalmology lies in the questiondoes or does not each hereditary disease cause blindness?

The definition of blindness throughout the world varies greatly, but I will refer briefly here to the definition employed by the Government of the Commonwealth of Australia. It is, "Loss or diminution of vision to an extent which renders the sufferer unfit for work other than that usually performed by blind workers." With this definition as a guiding principle, certification for blind pensions is made throughout Australia, and the survey made by W. D. Counsell and myself (1936), into the causation of blind ness in Tasmania, was carried out on the principle of this definition. A second difficulty in estimating the causation of blindness, is lack of an international classification of causes. We found when making our review that one disease might be put under several headings. A third difficulty was the incomplete data which was due to two factors : $(a)$ certification by incompetent referees, $(b)$ vague and incomplete certification forms.

A fourth difficulty was that many of the aged blind received old age pensions, and not blind pensions. And fifthly, the personal factor, i.e., that competent referees vary in their opinion of causation.

The survey made for the Commonwealth Health Council by W. D. Counsell and myself (1936) into the causes of blindness in Tasmania (now published in the 1st Report of the National Health and Medical Research Council of Australia) reveals at least 170 cases from pension and other sources. (See Table IV.) Of these 
170 , no less than 78 were unreliable in clinical data, and of these 78 no mention was made at all of the causation in 36 cases. Of the remaining 92 , no less than 35 were blind from hereditary causes which is in the surprisingly high proportion of 38.04 per cent. Of these 35 cases, 19 were blind from hereditary cataracts, 10 from Leber's disease, 3 from retinitis pigmentosa, and 2 from detachments of the retina, and one from nystagmus. (See Table V.) I could easily. have raised this percentage by including glaucoma and myopia, but 37.7 per cent. appears to me to be quite high enough to warrant action. The necessary action will be discussed under prevention, but it suffices to say here that a further 23 of these 92 cases appear to me to be preventable, thus making a total of 58 or 63.04 per cent. of definitely preventable cases. I consider it the privilege and duty of the medical profession to act, and to act quickly in this matter. The public are now sufficiently enlightened to co-operate if carefully led.

In conclusion let me quote Best (1934), in his summary of the prevention of blindness in general and not hereditary blindness ir: particular:-

“ Thus we find what seems to be a fair estimate, 72 per cent. or not far short of three-fourths of the blindness in the United States of America to be of preventable character."

My minimal estimate for Tasmania is 63.04 per cent. (see Table IV), which is just two-thirds.

TABLE IV

Major Causes of Blindness in Tasmania

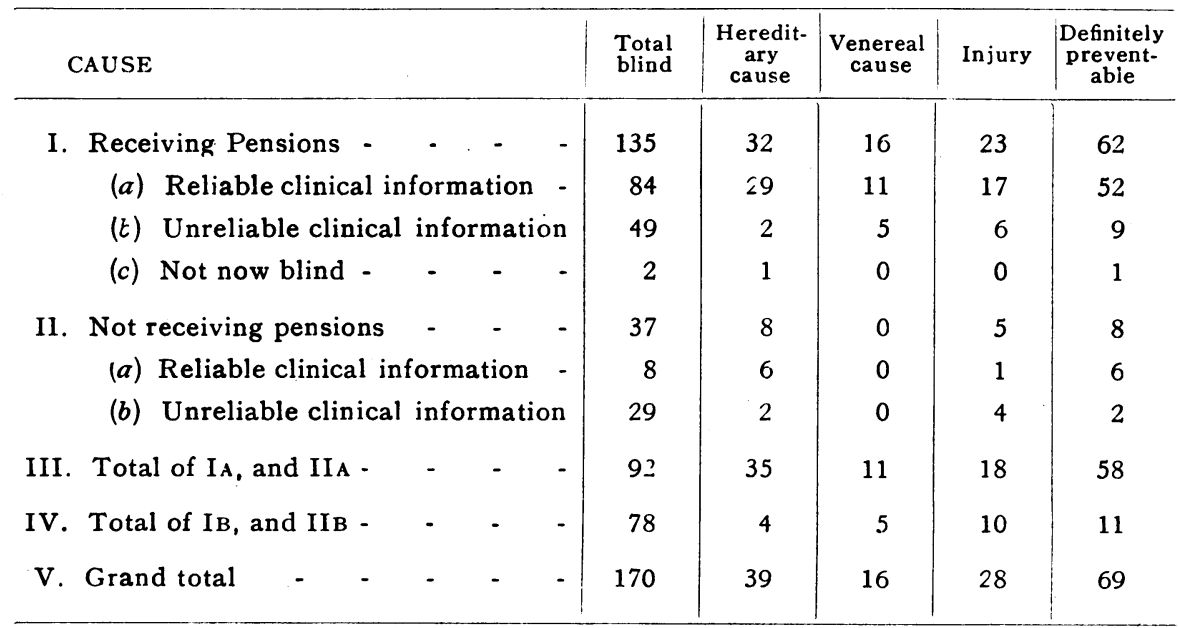


TABLE V

Causes of Hereditary Blindness in Tasmania

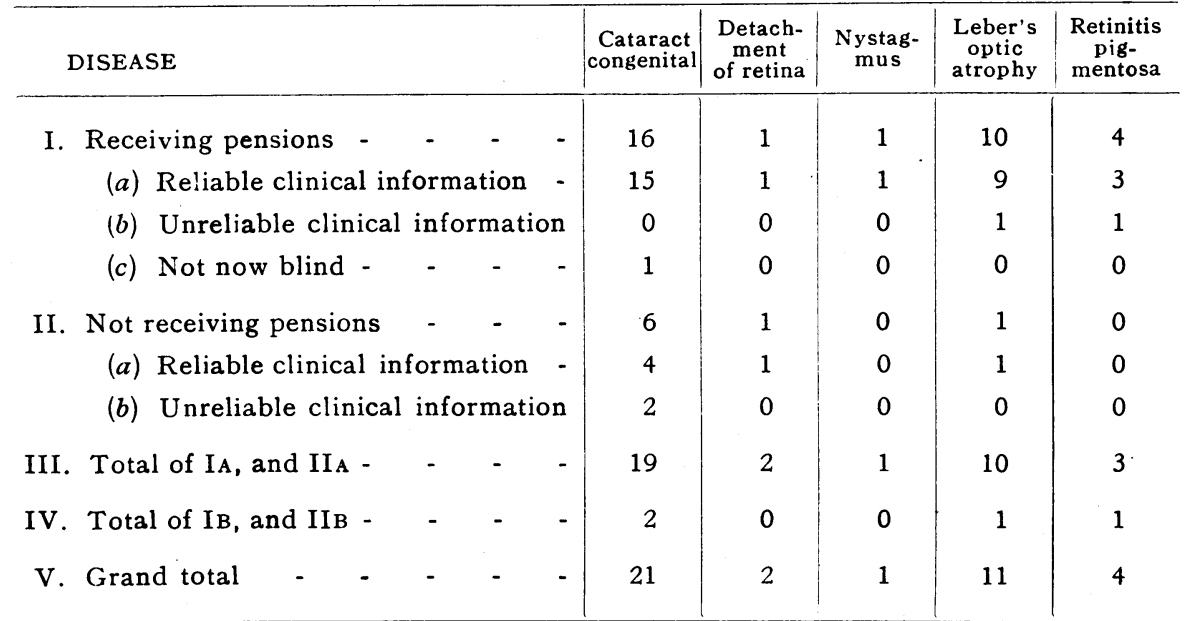

\section{REFERENCES}

BEST, H. (1934).-Blindness and the Blind in U.S.A. 2nd Edition. New York. Counsell, W. D., and Hamilton, J. B. (1937).-First report of Commonwealth, National Health and Medical Research Council.

League of Nations. (1929) - Welfare of the Blind.

MacCallan, A. F. (1935).-Brit. Jl. Ophthal,. Vol. XIX, p. 338.

Marquez, Prof. (1933).-XIV Concilium Ophthal. Hispania, T. III, 2-3, p. 106.

Prevention of Blindness CommitTeE of the Union of Counties AssociaTION FOR THE BLIND. (1933).--Report on Hereditary Blindness. London.

\section{Sociological Problems}

The Tasmanian Institution for the Blind, Deaf and Dumb has the following objectives in regard to the blind and deaf in the island of Tasmania.

1. To promote the education, industrial training, employment and general advancement in the life of the blind, deaf, and dumb and their social, economic, and spiritual welfare.

2. To undertake measures for the saving of sight, and the correction of defects of speech.

3. To provide buildings, premises, equipment, materials, and facilities for any such purpose as aforesaid.

4. To co-operate and collaborate with any person or organisation having any similar aims for any of the purposes aforesaid.

The Institution is administered by a Board of Management on which sit representatives of the State Government, the Braille 
Writers Association, and Subscribers, and it has entire control of all sociological problems relating to the blind.

The sociological problems relating to sufferers from hereditary eye diseases cover an even wider field, and include the normal sighted, the partially sighted and the blind. I propose dealing with these problems under the following headings :-

1. Education.

2. Employment.

3. Welfare.

4. Prevention.

And to pay special attention to the work undertaken in Tasmania in these directions.

\section{Education}

Children and adults with hereditary eye defects naturally fall into five classes as far as educational facilities are concerned.

1. Normal sighted-to $6 / 12$-non progressive.

2. Normal sighted with progressive lesion-e.g., myopia.

3. Partially sighted-non progressive-e.g., nystagmus $6 / 18$ to $6 / 36$.

4. Partially sighted-progressive lesion-e.g., retinitis pigmentosa.

5. Blind-6/60 or less.

(a) Primary education in institutions.

(b) Higher education.

(c) Home tuition.

(d) Deaf Blind.

1. Normal sighted.-The main duty of the ophthalmic surgeon is to ascertain that the condition is non-progressive, and the Committee of Enquiry into the Problems relating to partially-sighted children (Crawley, 1934), stresses in more than one page of its report, the necessity for the half-yearly examination of the partially sighted, and I feel this provision should be extended to the normal sighted known to have inherited eye defects, for the above reasons at least. These normal sighted children can be educated along ordinary lines so long as their condition is non-progressive, but should they show signs of deterioration, then the ophthalmic surgeon in charge of the case or school, must recommend the transfer to group 2. On the other hand, hypermetropes after adequate correction and continuous use of their glasses may show a marked improvement in visual acuity, which necessitates the surgeon transferring these cases from group 2 back to group 1 .

2. Normal sighted with progressive lesions.-In this group, which chiefly includes the myope, the opinion of an ophthalmic 
surgeon of experience is absolutely essential in deciding the merits of each case. The Crawley Report on Partially Sighted Children lays down on page 23 criteria for the special education of myopes.

At the same time on pages 32 and 33 the Report stresses the fact that once the myopia has ceased to increase more than $\frac{1}{2}$ dioptre per annum, and provided the vision and fundus changes are satisfactory, such children should be re-drafted to ordinary schools (group 1). On the other hand, if the malady is rapidly progressive, the child may be forced to enter a blind school in order to complete its tuition. On page 35 the necessity of a bi-annual examination by ophthalmic surgeons of all scholars of partially sighted cases is stressed.

I particularly stress the education of myopes, for at present the educational trend is to divide those with hereditary eye defects into 3 classes, educationally :-

1. Normal sighted.

2. Partially sighted including myopes.

3. Blind.

This is unfortunate, for myopes should not be educated together with the partially sighted as they (myopes) require restricted use of books, and physical exercises.

3. Partially sighted-non progressive.-Group 3 are stationary pupils in the partially sighted class, and their education should run along uninterrupted lines.

4. Partially sighted-progressive.-Group 4 is a difficult one, and just when they should be transferred from the partially sighted class to the Blind Institution must again be decided by the ophthalmic surgeon at his regular periodic examinations. The Crawley Report (1934) on page 25 recommends the education of these patients in "partially sighted" schools as long as practicable. It also devotes the whole of chapter $\mathrm{V}$ to weighing the pros and cons of segregation versus non-segregation of the partially sighted, and after a full survey of the merits of each, concludes the discussion in favour of the partially sighted not in schools for such, but in special classes in ordinary schools. The final paragraph to the chapter is as follows :-

"After balancing the advantages of the segregation and non-segregation systems, and recognising fully the difficulties which must be overcome, and the prejudices which must be broken down, the Committee recommends that the education of partially sighted children should be conducted where possible in special classes attached to, and forming an integral part of, the ordinary school. This decision has only been arrived at after studying this system in America, where it is used extensively, and at Liverpool where it has been found most satisfactory." 
Myer (1930) in his survey of Sight Saving Classes in the public schools of the United States of America details some of the standards of admission to such classes in America. Variation in the different States is enormous, and the National Society for the prevention of Blindness has given the following guide for finding potential sight saving class (not school) pupils, but they stress emphatically that all cases must be considered individually :

(i) General Statement, children having a visual acuity of 20/70 (Snellen 6/12) or less in the better eye after proper refraction. In addition the following are recommended as potential candidates :-

(a) Children in elementary schools having four or more dioptres of myopia.

(b) Inactive, subsiding (or regressive) cases, such as interstitial or phlyctenular keratitis, optic neuritis, trachoma, etc., in which some irritation may be present, provided the approval of the attending physician is given.

(ii) All cases must be considered individually.

(iii) Any child who in the opinion of the ophthalmologist would benefit by assignment to a sight saving class, subject to suggestion for treatment and training by such ophthalmologist, and the acceptance of the educational authorities having charge of such classes.

(iv) It is assumed that all the children assigned to sight saving classes have average normal mentality.

5. Blind.-Although group 5 appears straightforward, complaints have arisen in the past, due to the failure of the necessary authorities, to have all candidates for Blind Schools examined by an ophthalmic surgeon before admission. The Crawley Report (1934) describes the education of the partially sighted in the blind institution as " indefensible "-not only does such an education stigmatise the partially sighted, but also it is quite inadequate for their needs in after school life.

(a) Primary Education in Institutions.-Schools for blind children have been instituted in practically every country, but in some they have been incorporated with classes for the deaf also. This, to some extent, is unfortunate, as each defect has entirely different problems, and Best (1934) points out that, as in many institutions, the blind are in the minority, their education is subordinate to that of the deaf. But for financial reasons in smaller states and countries his combination is unavoidable although not ideal. It must be remembered that Best (1934) states that it costs 
eight times as much to educate each blind child in a residential institution as it does to teach each sighted child in a day school. For transport reasons most blind schools are residential, but the ideal methods of tuition are day schools, which can only function satisfactorily in larger cities. Further, schools for the blind should be as far as possible treated as educational rather than charitable institutions, for to stigmatise the education of the blind as charity is not in accord with the trend of modern thought. Education, nevertheless, should be compulsory for at least 9 years, i.e., from 7-16 years of age; and if higher education is desirable and desired, it can be undertaken on a voluntary basis.

(b) Higher Education.-This group contains those whe through special adaptability qualify for higher education. This can at first be undertaken at High Schools, and later at a University. The number of blind, able to pass the necessary examination even with the aid of a sighted coach and Braille writer is extremely limited.

(c) Home tuition.-This group is usually carried out by the Welfare (or Field) Officers, and is almost totally confined to adults whose blindness has supervened after school life, and who wish to learn Braille or Moon. For the elderly blind the Moon type appears to be indispensable.

(d) Deaf Blind.-This group can seldom come within the scope of this paper, and when some hereditary blind child does become afflicted with deafness it is wise to educate him with the blind rather than the deaf.

\section{Local Conditions}

In the Commonwealth of Australia there are 6 States, and in each state capital a blind school is situated, primarily for the education of blind children, but also catering for a limited number of partially sighted. In no part of the Commonwealth has any attempt been made to organise separate classes or schools for the partially sighted or myopes. This I have been at pains to verify by letters addressed to each blind school within the Commonwealth.

At present in Tasmania I am making a determined effort, with the aid of the Director of Education, to establish at least one class for the partially sighted, both in Hobart and Launceston; and a rough survey of metropolitan schools in Hobart is being made to this end. But unfortunately the present government is not sympathetically disposed to the project, and the matter may have to be dropped. It might be mentioned here that the routine examination of the eyesight of school children within Tasmania 
is at present carried out by the school nurses, and the survey mentioned above proves conclusively that many children with poor eyesight attending school have never received attention either from an oculist or optician. Both the lack of expert medical supervision and the lack of appropriate treatment is greatly to be regretted.

In 1906 compulsory schooling for the blind and deaf in Tasmania was introduced by legislation, and 7-16 years defined as the appropriate span of tuition for those so affected. It is now felt that if these afflicted children could commence their education at an earlier age, better progress would be made. But further legislation must be enacted to bring this about, and at the moment the government is not disposed to act.

A residential school at the Tasmanian Institution for the Blind caters for these children, but happily to say there are now only six, four of whom have hereditary blindness, attending the school from the whole of Tasmania-a most gratifying fact. The cost of teaching the children is undertaken by the State Education Department, while the State Government contributes $£ 18$ per annum per head for maintenance and board. Parents occasionally contribute towards their children's upkeep, but none to a greater extent than $£ 26$ per annum.

Higher education is also in force in Tasmania. Two boys, aged 16 years, are at present attending the State High School, and are showing very creditable examination results. While another young man, having matriculated, has commenced his Arts course at the University of Tasmania, with a view to becoming ultimately a teacher of the blind. The High School education is free, while the Tasmanian University has waived the collection of fees in the individual case mentioned.

Home tuition is also carried out extensively by the Welfare Officer, and by adults who have been blind from childhood, and is proving most satisfactory.

\section{REFERENCES}

Australian Blind Institutions. (1936). - Personal Communication. BEsT, H. (1934).-Blindness and the Blind in U.S.A. 2nd Edition. New York.

Crawley, R. H. (1934).--Report of the Committee of Enquiry into Problems Relating to Partially Sighted Children.

League of Nations. (1929).-Report on Welfare of the Blind.

National Institute for the Blind. - A Handbook on the Deaf Blind. Bulletin No. 4. London.

Tasmanian Institution for the Blind (1936).-Personal Communication.

Tasmanian Institution for the Blind. (1936). - Annual Report.

Myer, E. T. (1930).-A Survey of Sight Saving Classes in the Public Schools of U.S.A. New York. 


\section{Employment}

Persons suffering from hereditary eye diseases should be classified as regards employment, under four headings :-

(1) Normal sighted, (2) Myopes, (3) Partially sighted, (4) Blind, and will be dealt with in this order; with special references to conditions pertaining thereto in Tasmania.

1. Normal Sighted.-Except in rare instances such as the colour blind, these people can avail themselves of any offered occupation. The modern use of red and green signal lights precludes the colour blind from aerial, marine, and transport pursuits, and from certain branches of the textile industry.

2. Myopes.-Nothing has been done for myopes in regard to employment, either in Tasmania or Australia, but when a move is made in this direction within the Commonwealth, the investigations of the Board of Education Committee on the Partially Sighted (Crawley Report, 1934), should not be lost sight of in this regard. The Committee of Enquiry found that the myopes tutored in special classes deteriorated more rapidly in after school years than their fellow myopes tutored in ordinary schools, and they suggest that it appears important that dioptre saving must be continued in after school years to be effective. Consequently occupation should be found for myopes which does not entail lengthy periods of close work, or much bending or straining.

3. Partially Sighted.-With regard to the partially sighted in England some organised attempt has been made to find suitable employment for those people after they leave the sight-saving classes, but so far the result is disappointing. In Australia and Tasmania there are no sight-saving classes, and no attempt has been made to place these people in suitable occupations such as distributing trades, farm work, gardening, canvassing, and domestic duties. Consequently they find the most remunerative occupation for which they are capable, without respect to suitability, this is most regrettable and certainly needs rectifying.

4. Blind.-The employment of the blind has been a most difficult problem ever since Valentin Hauy first instituted it in Paris in 1748. There appear to be two main difficulties. First, to find suitable employment, and secondly to dispose of the articles manufactured at a profitable rate; at the same time it must be remembered that on account of mental, physical or temperamental disabilities at least 65 per cent. of the blind are unemployable (League of Nations Report, 1929). Best (1934) estimates that only 7.7 per cent. of the blind in the United State of America are seff supporting. Since the War, many countries have attempted to find fresh employment for sightless workers, and in some instances 
blind men and women have been incorporated in sighted teams, working in industrial concerns of various types. For instance, in England (League of Nations Report, 1929), 5 girls work in a team at Messrs. Cadbury, Fry and Pascall's factory packing chocolates; and another 5 at Messrs. Wells, Ltd., on tin toys; and certain processes in soap factories have been declared suitable for blind workers. In Germany this branch has been developed to an extraordinary degree, and 218 occupations have been found amongst sighted workers. On the other hand it is only natural that many employers have avoided utilising the blind in their factories on account of the fear of accident, and the resulting consequences under the various Worker's Compensation Acts. In Tasmania no attempt has been made in this direction, nor have the potentialities of subcontracting (N.L.B. Bulletin No. 1) been investigated to any extent.

In Australia the occupations of the blind are almost entirely confined to broom making, brush making, mat making, piano tuning and music. In Tasmania there is one workshop at the Tasmanian Institution for the Blind, where brush, mat, and basket making are the predominating industries. At present 29 blind men, and 3 blind women are employed there, and the articles manufactured are sold in their own city shop. During the past financial year, articles to the value of $£ 4,790$ were sold, being an increase of $£ 800$ over the previous year. Each blind operative, besides receiving a blind pension of 18s. per week from the Commonwealth Government, has his or her wages augmented by the Institution, so that each single operative receives in all $£ 2$ 18s. 0d. per week, and each married operative $£ 3$ 3s. 0d. per week. During the year under review the factory showed a profit of $£ 180$, but as $£ 1,640$ had to be paid in augmentation the profit was turned into a loss of $£ 1,460$.

Besides this the Welfare Officer of the Institution and her Assistant instruct the blind women in cooking, towel hemming, tatting, knitting, crochet and bead work, from the sale of which they make a few shillings profit each week. So far weaving has not been introduced into their activities.

Music and piano tuning also find employment for a few blind men, but the advent of the radio has greatly reduced the number of pianos requiring tuning; and the advent of the talkies has thrown a great many professional musicians out of employment. This is most unfortunate as these two occupations are probably the most remunerative available for the blind. Here again the scope of employment for the blind is extremely limited, and an enquiry into possible new trades for the blind is being carried out in Australia at the moment. Gardening has not been systematically attempted in Tasmania, but has been taught to several 
blind children and adults, in view of the satisfactory results obtained since 1920 by the Guild of Blind Gardeners of Great Britain (N.I.B. Bulletin No. 3). Massage courses have not been instituted in Tasmania and therefore are not available for the blind.

\section{REFERENCES}

BEst, H. (1934).-Blindness and the Blind in U.S.A. 2nd Edition. New York. CRAWLEY, R. H. (1934).--Report of the Committee of Enquiry into Problems Relating to Partially Sighted Children.

LEague of Nations. (1929).--Report on the Welfare of the Blind.

National Institute For THE Blind.-Basket Making by the Blind. Bulletin No. 5. London.

National Institute FOR THE Biind.-Employment of the Blind, Bulletin No. 1. London.

National Institute For The Blind.-Gardening for the Blind. Bulletin No. 3. London.

Tasmanian Blind Institution.-Annual Report, 1936.

\section{Welfare}

The welfare of the blind in Tasmania is undertaken by the Tasmanian Institution for the Blind, Deaf and Dumb, and closely follows that undertaken in other parts of the world. It is arranged under the following headings :-

(1) Children of pre-school age, (2) Children from 7-16, (3) Adult Blind (a) Employable, (b) Unemployable and Necessitous, and naturally includes those suffering from the various causes of hereditary blindness.

(1) Children of pre-school age are visited by the welfare officer as occasion arises, and instructions are given to parents along orthodox lines.

(2) Children from 7-16. These are educated in a residential school attached to the Institution, and education is compulsory from the age of 7-16. Like the public schools, 3 terms a year are arranged and the children return to their homes for the vacations.

Any pupil showing high scholastic attainments is specially tutored for the qualifying examination of the State Education Department, the passing of which examination makes the pupil eligible for a High School Education. Later they may qualify for University entrance.

(3) Adult Blind.-At the present time there are 135 persons receiving blind pensions in the State of Tasmania, and of these, 29 men and 3 women are employed in the factory attached to the Institution where brush, mat and basket making are undertaken. The remaining are unemployable to a great extent, or are engaged in minor pursuits, such as cooking and sewing. This is comparable to the figures in England and Wales, where about 70 
per cent. of the blind are unemployed owing to age, mental weakness or other defects.

Those not attending the factory are placed under the care of the welfare officer and her assistant, but to date there is no residential home for either old men or old women, as it has been found more satisfactory to find lodgings for them in the homes of the sighted. Best (1934) considers that such special homes should only be instituted as a last resource, and on the whole are objectionable.

Certain facilities are provided for the adult blind either by the State or Commonwealth Governments, State Municipalities, the Tasmanian Institution for the Blind, or by other sources.

(a) Free tram passes by the City Councils of Hobart and Launceston.

(b) Free railway passes by the State Government. These allow each blind person and guide to travel for the fare of one. In special instances free passes for the blind travelling alone are issued.

(c) Free theatre tickets by theatrical and motion picture companies.

(d) Free radio licences by the Commonwealth Government.

(e) Radio sets either free or at cost price, by the Institution for the Blind.

(f) Pensions have been paid by the Commonwealth Government since 1910. These are at the rate of 18s. per week ( $£ 4616$ s. 0d. per annum) for all blind adults over 16 years of age, whose total income from pension and other sources does not exceed £221 per annum. Re-examination is seldom undertaken, so that undoubtedly certain pensioners who have received benefit from treatment still retain their pensions despite the fact that they are able to earn a livelihood.

(g) Augmentation of wages and pensions by the Tasmanian Institution has been mentioned under employment. It suffices here to say that each single operative receives in all $£ 218 \mathrm{~s}$. 0d. per week, while married operatives receive an extra 5s. per week.

(h) Retiring allowances by the Tasmanian Institution. On a blind operative reaching the age of 65 he or she is retired from the factory and a grant of 12s. 6d. per week is made from the Institution funds towards his or her upkeep, in order to supplement their pension of 18s. per week.

(i) A Medical Union supervised by the Tasmanian Institution. All blind pensioners by contributing $8 \mathrm{~s}$. per annum to the fund receive all medical consultations, and all medicine free -also dental attention at cost price. 
(j) Braille Writers' Association. Members of this association which works under the auspices of the Institution, take responsibility for all transcribing, importation of literature, training of Braille writers, supervision of Braille Library, and other social activities.

(k) Braille Mutual Progress Society also under the aegis of the Institution takes responsibility for weekly social gatherings, which include lectures, card evenings, play readings, and dances. Also visits to museums have been experimented with.

(l) Library and talking Books. The former is controlled by the Braille Writers' Association and financed by the Institution. (Free postage of books is permitted by the Commonwealth Government.) Two of the latter have been purchased by the Institution but are not yet to hand.

From the above account it will be seen that every effort is being made in Tasmania to cope with the problems appertaining to the welfare of the blind, and it is hoped before long, that the Institution's activities will be broadened to cover the partially sighted also.

\section{REFERENCES}

BEST, H. (1934).-Blindness and the Blind in U.S.A. P. 460. 2nd Edition. New York.

Crawlev, R. H. (1934).-Report of Enquiry in Problems of Partially Sighted Children.

LEAGUE OF NATIONS REPORT. (1929).-Welfare of the Blind.

NATIONAL INSTITUTE FOR THE BLIND.-Care of the Blind Baby. Bulletin No. 6. London.

National Institute for the Blind.-Handbook on the Deaf-Blind. Bulletin No. 4. London.

National Institute for the Blind.-Museums and the Blind. Bulletin No. 2, London.

Sutton, H. (1935),-Med. Il. of Austral., April 6, p. 417.

TASMANiAN INSTITUTION FOR BLIND. (1936).-Annual Report.

\section{Prevention of Hereditary Eye Disease}

Blindness throughout the world has lately so concerned social workers and Governments that International Associations for the Prevention of Blindness and against trachoma have been set up, as well as much legislation passed to check its apparent increase. As a result of this legislation, blindness from smallpox and ophthalmia neonatorum has greatly declined, while the ravages of trachoma have been slightly checked. But little attempt has been made to check the enormous disability of hereditary eye disease, probably because of the lack of reliable data. In Tasmania I find that 37.7 per cent. of the blind are suffering from hereditary diseases of the eye, while Miles Bickerton (1934) estimates that 
24 per cent. of the blind of Great Britain suffer from hereditary eye disease, i.e., 1/4 of the total blind, and he suggests possible remedies. Who, on reading this list of remedies can honestly suggest that more drastic legislation is not long overdue? Bickerton asserts that our present outlook is inhuman-with which I agree-but the difficulty is to persuade the public that reform is urgently necessary. Most men and women approach the subject of heredity in two ways, according to Eldon Moore (1934), either as " a mysterious tricky affair responsible for all those queer things in men, which cannot be explained otherwise, or else it is looked upon as a sort of fatalistic demon whose existence all nice minded people should ignore"; and Eldon Moore continues, "Actually the hereditary mechanism is the most important part of all living things." I feel that very few have grasped the truth of this last sentence.

Franceschetti, before the 1935 meeting of the International Association for Prevention of Blindness, suggested the following measures for diminishing the incidence of hereditary blindness :-

(a) Collection of precise and complete statistics.

(b) Training of physicians (especially ophthalmologists) in genetics, and the education of authorities and the public.

(c) Extension of facilities for pre-marital consultation, and the general introduction of pre-marital certificates.

(d) Increased use of social workers.

(e) Decrease in consanguineous marriages.

(f) Decrease of the transmission of hereditary eye disease, by making sterilisation available to the patient.

No one can fail to agree with every one of the above suggestions.

Let me discuss each of these suggestions, and especially the last suggestion of sterilisation, for its effects would be more far reaching than any of the others.

(a) Collection of precise and complete statistics.-With regard to this recommendation, the Report on the Prevention of Blindness (1936), repeatedly stresses the fact that uniform certification of Blindness is essential before dependable statistics can be compiled. It suggests four improvements in this direction, namely:

(1) A universal form for examination and report on all blind persons admitted to the register, and it published in detail the form recommended by the Ministry of Health (1933) in their circular number 1,353 .

(2) A Universal Definition of Blindness, and it quotes the Ministry of Health's Circular Number 1,353 which includes such a definition. 
(3) The Certification of the blind should be undertaken only by a "medical practitioner with special experience in ophthalmology," and it quotes the Ministry of Health's definition of such a term in their circular number 1,353 .

(4) The collection of such statistics by a select sub-committee authorised by the Ministry of Health, and the Board of Education is essential. Authority to form such a Committee and to tabulate the statistical findings, has been given to the Prevention of Blindness Committee.

Within the Commonwealth of Australia, which includes Tasmania in its certification laws, there is absolutely no attempt to compile reliable statistics of the causes of blindness. No form other than that for invalid pensions in general is provided; no detailed definition of blindness has been formulated, and no statistics are kept of the certified blind. Further, the services of experienced ophthalmologists to certify the blind, are not obligatory, but the Commonwealth Pensions Department is now taking the necessary steps to have this rectified.

(b) Training of physicians in eugenics, and education of authorities and public.- The Prevention of Blindness (1936) report is emphatic that the training of medical men in ophthalmology is inadequate, and recommends the close attention of the General Medical Council to this fact. The training of medical practitioners, and the education of authorities, and the public in general in genetics has been advocated for many years by the Eugenic Society, but has enlisted little support. Obviously man does not wish to face facts where reproduction of his species is concerned.

(c) Extension of facilities for pre-marital consultation, and introduction of pre-marital certificates.-Like sterilisation to be discussed in detail later, this recommendation will obviously receive the whole-hearted disapproval of the populace. Yet a stand must be made sooner or later to combat the evil results of the propagation of hereditary disease. But just where to start concerns every social worker. I think it was Bernard Shaw who said " First choose your parents." It certainly appears to many (and also to me) that some public body should actually choose our parents. Men and women should not be allowed to mate with less respect to eugenics than is shown in breeding of domestic animals. Every couple intending to marry should be forced to appear before a tribunal, present their pedigrees for scrutiny and approval, before marriage is allowed.

Legislation of this type is already in vogue in Roumania, but in no other country has it been attempted up to the present. Those rejected should be advised of the reasons, and suggestions given for treatment. If the reasons for rejection are hereditary 
disease, then means should be taken to prevent rejected persons from breeding.

(d) Increased use of Social Workers.-In this regard much excellent work has been done in the past, but there is gigantic scope for enlargement in the near future, especially in regard to out-patient work in special hospitals, and general hospitals with large ophthalmic departments.

At present in Tasmania except for the Welfare Officer attached to the Tasmanian Institution for the Blind, there is no Social Worker or Almoner attached to any of the large public hospitals or institutions. Some three years ago one trained Almoner was appointed to the Hobart General Hospital, but after twelve months excellent work, her appointment was terminated and the office classed as unnecessary.

(e) Decrease in consanguineous marriages.-Later in this work where consanguinity is discussed in conjunction with nystagmus, optic atrophy and retinitis pigmentosa, it should convince the most ardent sceptic that consanguineous marriages are ill-advised, and should be legislated against at once. Best (1934) considers that " the proportion of the blind with blind relatives is over three times as great among those whose parents are cousins, as it is among the blind as a whole." Surely this is sufficient.

(f) Sterilisation.-At the end of 1933 the following countries throughout the world had passed sterilisation laws :-

26 States of the United States of America-principally in the West. 24 of these States have compulsory laws, and 2 have voluntary ones.

2 States of Canada, both of which have voluntary laws.

1 Canton of Switzerland.

Germany, where sterilisation is compulsory.

Denmark, with a voluntary law.

Except in the case of Germany, none of the above mentioned countries enacted laws on sterilisation to deal with hereditary blindness, but in the main they deal with mental cases and feeblemindedness.

None of the six States of the Commonwealth of Australia has made any move in the direction of laws for human sterilisation, with the exception of Tasmania, but an inquiry into the subject under discussion should be a matter for investigation by the Common wealth Government and not by States individually.

The Broche Report on Sterilisation (1933) was very guarded in its recommendations, and suggested very limited legislation to deal with the propagation of the unfit. For many reasons it was opposed to compulsory sterilisation, but strongly advocated the voluntary sterilisation, not only of the mentally unfit, which was 
its limited reference, but also certain forms of hereditary blindness, deafness, haemophilia and brachydactyly, etc. This I feel certain will never be satisfactorily accomplished unless the physical results are expounded to the public in clear straightforward terms.

Hereditary diseases of the eye have always interested the eugenists particularly in view of the certainty of diagnosis in experienced hands. The Broche Report of the Departmental Committee on Sterilisation (1933) found its enquiry into hereditary mental deficiency much embarrassed by the fact that there were so many degrees of mental deficiency, and so many borderline cases. This is not so with hereditary eye diseases which are clear cut, and well recognised diseases. Yet throughout the whole Broche Report (1933) there is only one practical instance mentioned (page 43) of the sterilisation of the hereditary blind. In view of the fact that so much has been done to prevent blindness in other directions, surely this new avenue of prevention should be utilised without delay.

On the subject of the legality of sterilisation, the above reports are quite emphatic. Legality of therapeutic sterilisation is not disputed, but the legality of eugenic sterilisation in the present state of the law in England is couched in the following terms on page 6, " but in practice it appears to be almost universally accepted that eugenic sterilisation is illegal, and involves the surgeon concerned in the risk of legal proceedings, even though the full consent of the patient has been obtained." On the other hand Beasley (1935) discussing the legality of the sterilisation of the unfit in Western Australia asserts, "Sterilisation performed at the request of a patient who understands the nature and result of the operation, and freely consents thereto, does not constitute a disablement within the meaning of section 294 (of the West Australian Criminal Code), and does not involve in criminal responsibility the surgeon who performs the operation."

H. C. Lewis, barrister at law, in a private communication in reference to the laws of Tasmania in regard to eugenic sterilisation, is of the opinion that it is inadvisable in this island under the existing laws.

If clear thinking men and women with inherited defects commence to ask for sterilisation, as has been the case in Tasmania, then the time is more than ripe for the Government of this Commonwealth to take the matter up, and have the proper legislation for voluntary sterilisation enacted without delay, to include not only the mentally unfit, but those suffering from all inherited diseases.

If this is enacted there is then a possibility of stamping out over half the preventable blindness in Tasmania. A most pleasing prospect. 
The words of Byron seem appropriate here :-

" Hereditary Bondsmen! know ye not

Who would be free, themselves must strike the blow ?"

-Childe Harold, 1-86.

\section{REFERENCES}

Beasley, F. R. (1935).-Med. Jl. of Austral., March 9, p. 295.

BEST, H. (1934).-Blindness and Blind in U.S.A. 2nd Edition. New York.

Bickerton, J. M. (1934).-Brit. Med. Jl., January 20, p. 93.

BROCK. (1934). - Report of the Departmental Committee on Sterilisation-Ministry of Health of Great Britain.

CommonWEalth of AUSTRalia. (1935).--Official Year Book, p. 514.

Commonwealth Bureau of Census and Statistics.-Private Communication.

CRISP, H. R. (1935).-Med. Jl. Austral., March 9, p. 303.

FrANCESCHETTI. (1935).--Report of the International Association for Prevention of Blindness, p. 14.

McWhaE, D. M. (1935).-Med. Jl. Austral., March 9, p. 298.

MOORE, E. (1934). - Heredity-Mainly Human. London.

Standing Committee on the Prevention of Blindness of the Union of Counties' Association for the Blind. (1936).--Report on the Prevention of Blindness.

Sterilisation of THE Unfit. (1935).-Discussion Med. Jl. Austral., March 9, p. 318.

SwaB, C. M. (1934).-Nebraska Med. Jl., Vol. XIX, pp. 184-187.

TAsmanian Institution for the Blind. (1936).-Personal Communication.

Thompson, E. J. T. (1935).-Med. Jl. Austral., March 9. p. 301.

(To be continued)

\section{USE OF CONTACT GLASS FOR COSMETIC PURPOSE}

BY

S. K. MUKERJEE, F.R.C.S.(Edin.), D.O.(Oxon.), D.O.M.S.(Lond.)

PROFESSOR OF OPHTHALMOLOGY, CARMICHAEL MEDICAL COLLEGE, BELGACHIA, AND HONORARY OPHTHALMIC SURGEON, CALCUTTA MEDICAL COLLEgE hOSPITALS

THE indications for the use of a contact glass besides its use in the various forms of ametropia are recorded in the literature. In the March 1931 issue of the Lancet in the paper " on the use of Contact Glasses " by Leopold Heine, it was noticed that contact glasses might be used for cosmetic purposes. As illustrative cases of the above indication did not come to my notice, I venture to publish the following case of mine which proved to be very successful. 